\title{
Precooling techniques and applications for fruits and vegetables
}

\author{
- CHIMAN BALADHIYA ${ }^{1 *}$ AND JAYESH DOSHI ${ }^{2}$ \\ ${ }^{1}$ Sheth M. C. Dairy Science College, Anand Agricultural University, ANAND (GUJARAT) INDIA \\ ${ }^{2}$ Regional Research Station, Anand Agricultural University, ANAND (GUJARAT) INDIA \\ Email : csbaladhiya@gmail.com
}

*Author for Correspondence

Research chronicle : Received : 04.03.2016; Accepted : 27.05.2016

\section{SUMMARY :}

The temperature is the most important factor affecting the post harvest life and quality of fruits and vegetables. Quality loss after harvest occurs as a result of physiological and biological processes, the rates of which are influenced primarily by product temperature. As the maintenance of market quality is of vital importance to the success of the fruits and vegetables, it is necessary not only to cool the product but to cool it as quickly as possible after harvest. The process of precooling is the removal of field heat which arrest the deteriorative and senescence processes so as to maintain a high level of quality that ensures customer satisfaction. This review describes about importance of precooling, its considerations and calculations. Various precooling techniques and applications along with their merits and demerits for various fruits and vegetables are also summarized to have ready reference about selection of appropriate method.

KEY WORDS : Precooling, Fruits, Vegetables, Heat load, Storage

How to cite this paper : Baladhiya, Chiman and Doshi, Jayesh (2016). Precooling techniques and applications for fruits and vegetables. Internat. J. Proc. \& Post Harvest Technol., 7 (1) : 141-150. DOI: 10.15740/HAS/ IJPPHT/7.1/141-150 